\title{
The role of seasonal and occasional floods in the origin of extreme hydrological events
}

\author{
M. B. Kireeva ${ }^{1}$, N. L. Frolova ${ }^{1}$, E. P. Rets ${ }^{2}$, E. A. Telegina ${ }^{2}$, A. A. Telegina ${ }^{2}$, and N. N. Ezerova ${ }^{1}$ \\ ${ }^{1}$ Lomonosov Moscow State University, Moscow, Russia \\ ${ }^{2}$ Water Problem Institute, Moscow, Russia \\ Correspondence to: M. B. Kireeva (kireeva_mb@mail.ru)
}

Received: 16 April 2015 - Accepted: 16 April 2015 - Published: 11 June 2015

\begin{abstract}
Extreme hydrological events on the rivers of European part of Russia are closely related to the hydrological regime transformation answering recent climate changes. Rivers in this region used to be traditionally attributed to the Eastern-European type with well-pronounced seasonal flood wave and quite low flow period during summer and winter. During the last twenty years the role of the occasional floods became more and more important. Number of winter floods, connected with thaws rose dramatically, in the same manner as summer flash floods. In this study, the frequency and duration of extreme low flow and high flow events is analyzed. The deficits during hydrological year were calculated. Due to results increase in natural runoff regulation, does not reduce frequency of extreme events, in some regions it raises.
\end{abstract}

\section{Introduction}

The occurrence of extreme hydrological conditions associated with either high or low water content creates risks and economic losses associated with water use. Such hydrological events are rare in occurrence but typically affect large areas, resulting in a damage in several economic sectors. Only in the last five years there were three disasters like that. In 2010, the abnormal processes in the atmosphere and a breakdown of a typical atmospheric circulation led to deep water shortage that affected the most part the European territory of Russia. More than 40 temperature records were broken. The drought resulted in a large number of forest fires. Smog in Moscow on some days has reduced visibility to $100 \mathrm{~m}$ (Fig. 1a). Due to long-term water supply that was stored in reservoirs, large losses were avoided (Alekseevskiy et al., 2013). Water deficit was observed only in the Don basin and the Ural region. Thus, in the Belaya river basin navigation was completely closed for two months. On the Northern Dvina from the end of July till the end of August water level was below normal by $60-120 \mathrm{~cm}$. However, navigation was guaranteed by intensive and costly dredging. Next situation arose in winter 2012-2013, when snowpack in central Russia reached a height of $80 \mathrm{~cm}$ and more. This led to formation of a spring flood of very low probability. Water levels on the Oka River, for example, rose to a level close to dangerous. Most of the valley was flooded, including all levels of the floodplain. In dozens of settlements water came right up to the houses (Fig. 1b, c). In 2014, by contrast, it was a very warm and unstable winter. Water storage in the snowpack was minimal, resulting in the early start of dry season. The Volga reservoirs replenishment schedule was disrupted. The old city Mologa that was flooded by Rybinsk reservoir years ago, started to appear from under the water (Fig. 1d). Navigation on the upper Volga and Oka was stopped in July, causing multimillion losses to the cruise tourism business. According to RosHydromet (Federal Hydrometeorological Service), number of dangerous hydrolometeorogical events doubled from $150-200$ in the early 1990 s to $350-450$ by the end of 2000's (Fig. 2). Potential loss of each hazard can be up to EUR 1.3-1.6 billion according RIHMI - IDC (International Data Center). Under these circumstances, studying the prerequisites for the formation of extreme hydrological events is one of the most urgent problems in Russian hydrology. 

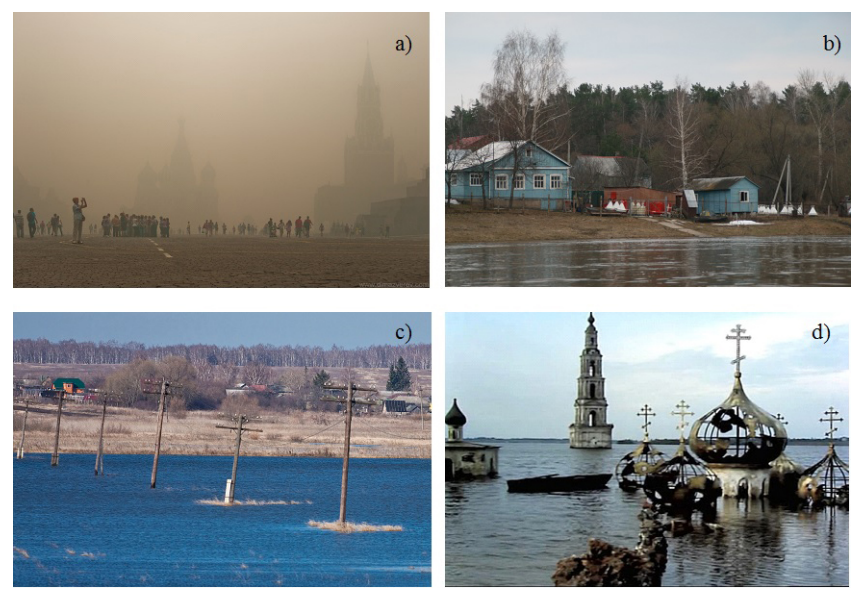

Figure 1. (a) Smog in Moscow, 2010 (D. Zverev's photo), (b, c) catastrophic flood in 2013 Oka river (N. Frolova's photo and A. Kamensky's photo), (d) flooded by Rybinsk Reservoir city Mologa, which came out of the water in 2014 (Y. Rassulin's photo).

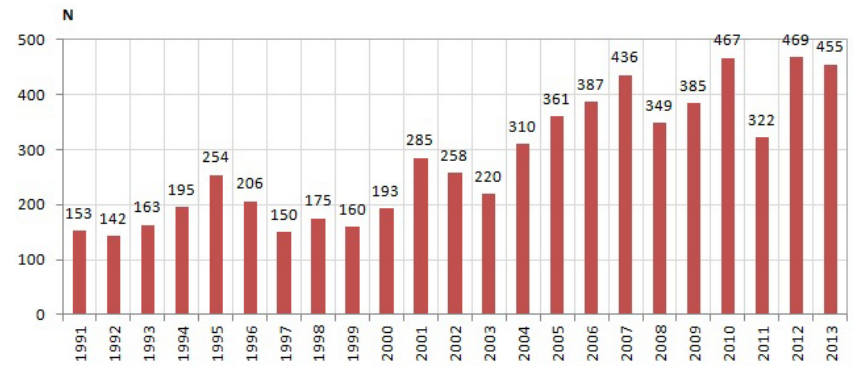

Figure 2. Number of dangerous hydrometeorological phenomena (http://www.meteorf.ru).

\section{Study area}

The European territory of Russia is a vast territory with an area of about 4 million $\mathrm{km}^{2}$. This region includes basins of river Volga, Don, the Northern Dvina, Pechora, Ural, and many others. Extreme hydrological events on the rivers of European part of Russia are closely related to the transformation of the hydrological regime due to the recent climate changes. Rivers in this region used to be traditionally attributed to the Eastern-European type with well-pronounced seasonal flood wave and quite low flow period during summer and winter. Currently, the ratio between runoff in different periods of the year is changing dramatically. Statistical and spatial analysis of data from 300 gauging stations shows, that these changes are represented by an increase in low flow and a reduced runoff during high-water period. For example, the low-flow period runoff of Don river increased almost twice from the first to the second half of the 20th century (Dzhamalov et al., 2013a). A similar situation is typical for the Oka and the Upper Volga, where the growth in low flow is about $50-70 \%$ (Dzhamalov et al., 2013b). In the Kama basin changes are less significant, about $15-30 \%$. For the northern rivers such as the Northern Dvina and Pechora, increased runoff in the low-water period is less pronounced and ranges from 5 to $15 \%$. For Mezen and Neva these changes are almost insignificant (Dzhamalov et al., 2014). Along with the increase in runoff in winter and summer a drastic reduction in the seasonal flood runoff is observed. The decline is most evident in those regions where the low flow period runoff is growing the most. In the Don basin the seasonal flood weakly stands out among many winter and spring flash floods, and the maximum discharge is halved (Kireeva and Frolova, 2013). Degradation of the seasonal flood is observed in the Volga basin too, the maximum discharges there reduced by $20-40 \%$. Thus, there is an equalization of intraannual flow distribution, and an increase in the natural runoff regulation rate. The details of these changes are discussed in Frolova et al. (2014). The main goal of this work was to determine the impact of water regime changes on the occurrence of extreme hydrological events.

\section{Materials and methods, results}

For an objective assessment of the impact of hydrological events on the economy the integral criteria are often used. They are based on the comparison of observed characteristics with the "threshold" values that were selected. According to the difference between the two, the impact of the event on people's lives and economy can be estimated. It is also common to take into account not only the actual difference, but the period of time for which the characteristic was exceeding the limit. These calculations allow to estimate the total deficit or excess of water. The resulting number corresponds with the duration of the phenomenon and represents an integral index of "severity" of the event. As a threshold it is most common to use the water discharge of specified repeatability. In this work, the analysis was made based on the threshold numbers of 10 and $90 \%$ probability discharges. 19 hydrological stations with the area more than $20000 \mathrm{~km}^{2}$ were chosen in different geographical zones for the analysis. The analysis was based on the monthly discharge data (Fig. 3).

Unit discharge, corresponding to the upper threshold values, varies according to changes in the zonal runoff. The highest values were found in the north-east of European Russia in the basins of Usa, Pechora, Vishera river - 49, 42, and $42 \mathrm{~L} \mathrm{~s}^{-1} \mathrm{~km}^{2}$, respectively. The average value for the north river is from 20 to $30 \mathrm{~L} \mathrm{~s}^{-1} \mathrm{~km}^{2}$ and decreases from north-east to south-west. Adjacent to the south basin of the Upper Volga, Oka and Ugra thresholds are reduced to 12$16 \mathrm{Ls}^{-1} \mathrm{~km}^{2}$. Kama River basin have significantly higher thresholds of runoff - an average of about $20-23 \mathrm{~L} \mathrm{~s}^{-1} \mathrm{~km}^{2}$. Minimum values are typical for the Don basin, especially Medveditsa river (less than $4 \mathrm{Ls}^{-1} \mathrm{~km}^{2}$ ). In the spatial distribution of low threshold observed a similar pattern. Low threshold ( $10 \%$ probability) more than $2 \mathrm{~L} \mathrm{~s}^{-1} \mathrm{~km}^{2}$ is typ- 


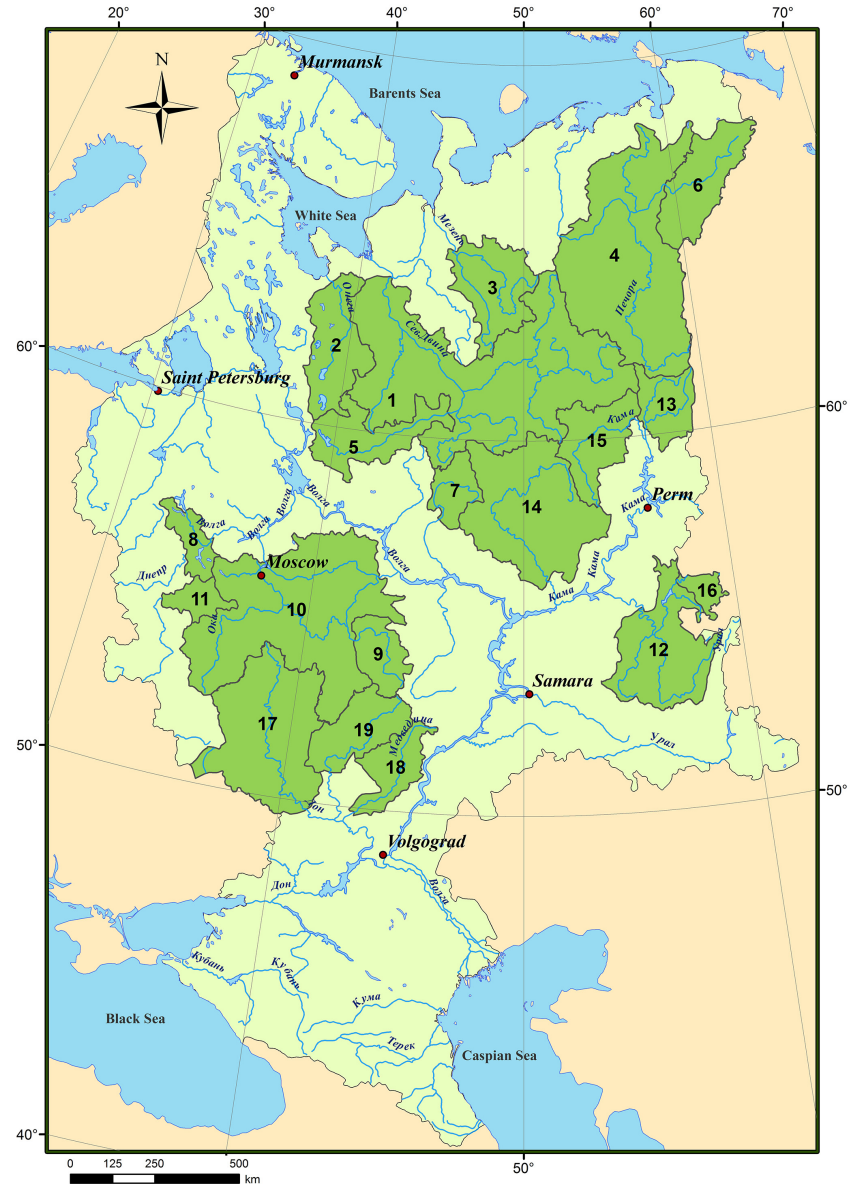

Figure 3. The map of representative basins (the numbers of the basins corresponds to Table 1).

ical for northern rivers of ETP. In the basins of the Upper Volga and Oka, it is reduced to $1.7 \mathrm{~L} \mathrm{~s}^{-1} \mathrm{~km}^{2}$ and Vetluga and Moksha $-1 \mathrm{Ls}^{-1} \mathrm{~km}^{2}$. In the Kama basin, the rate increases to $1.6-1.7 \mathrm{~L} \mathrm{~s}^{-1} \mathrm{~km}^{2}$. In the Don basin the unit discharge threshold is reduced to $0.5-1 \mathrm{~L} \mathrm{~s}^{-1} \mathrm{~km}^{2}$ (Table 1).

For northern rivers the number of cases that exceeds the high threshold value is between 60 and 75, in the basin of the Oka, Moksha and Ugra - about 70. In the Kama basin it increases reaching 80-87. Don basin number of exceedances is about 65 cases. The number of deficits on the contrary increases from 35-40 in the north to 50-60 in the south of European Russia. An interesting fact is that the number of extremely low and extremely high-water periods associated with each other: the more the river there is an extremely low monthly discharges, the more there is in it and extremely high discharges (Fig. 4).

The volume of deficit is clearly related to the volume of surplus, the correlation coefficient is greater than 0.9 (Fig. 5). Thus, every river, has some integral rate of "extreme", which characterizes the amount of water shortages and the number of highs. The more "extreme" is the water regime of the river,
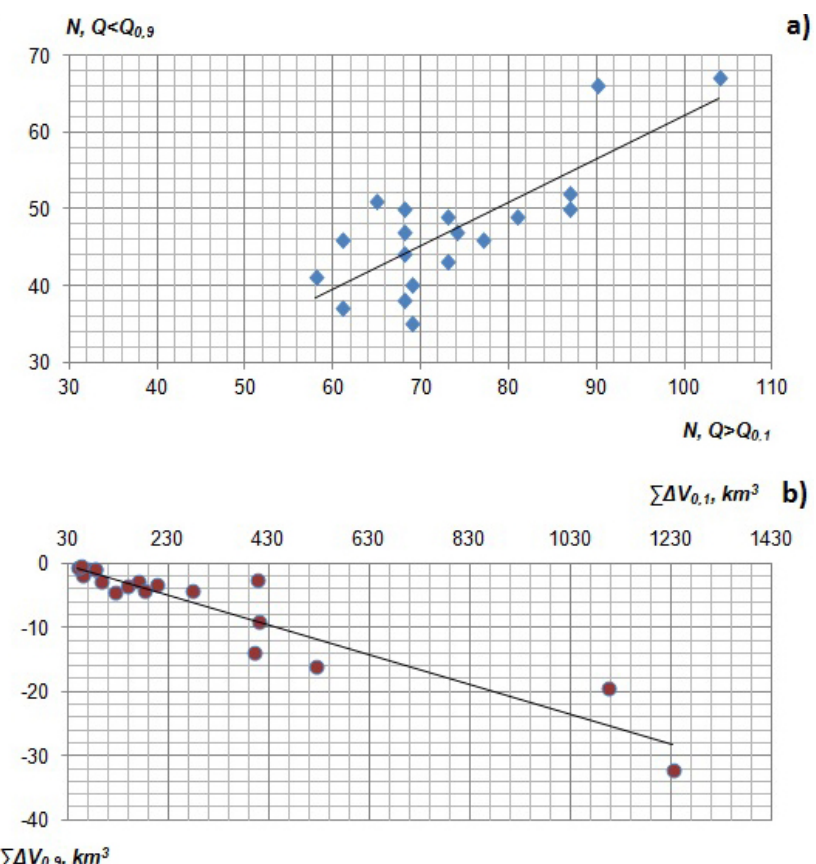

Figure 4. Relationship between the number of periods of extremely low and extremely high flow (a) and total volume deficit and surplus (b).
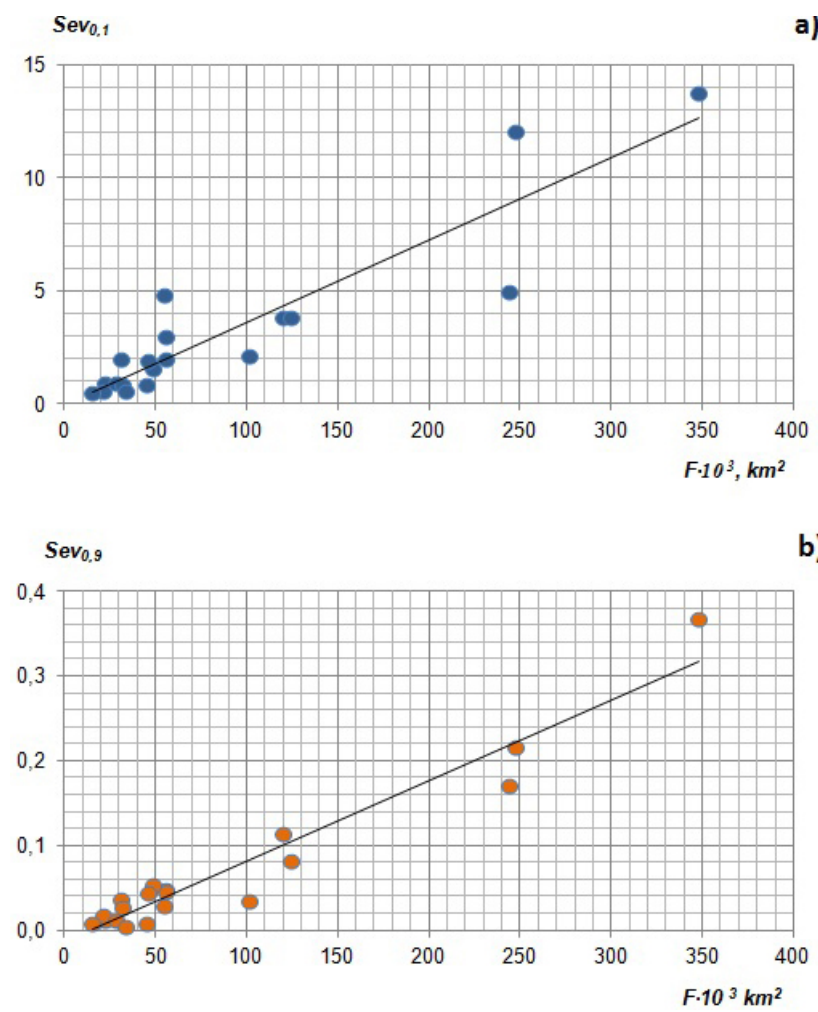

Figure 5. Dependency between the "severity" and catchment area for 0.1 (a) and 0.9 (b) probability. 
Table 1. Characteristics of extreme events for 10 and $90 \%$ probability threshold values.

\begin{tabular}{|c|c|c|c|c|c|c|c|c|c|c|c|}
\hline \multirow[t]{2}{*}{ River } & \multirow[t]{2}{*}{ Station } & \multicolumn{5}{|c|}{$Q>Q_{0,1}$} & \multicolumn{5}{|c|}{$Q<Q_{0,9}$} \\
\hline & & $\begin{array}{r}q_{0,1}, \\
\mathrm{Ls}^{-1} \mathrm{~km}^{2}\end{array}$ & $N$ & $\begin{array}{l}\Delta V, \\
\mathrm{~km}^{3}\end{array}$ & $\begin{array}{r}T, \\
\text { month }\end{array}$ & Sev & $\begin{array}{r}q_{0,9} \\
\mathrm{Ls}^{-1} \mathrm{~km}^{2}\end{array}$ & $N$ & $\begin{array}{l}\Delta V, \\
\mathrm{~km}^{3}\end{array}$ & $\begin{array}{r}T, \\
\text { month }\end{array}$ & Sev \\
\hline N. Dvina & Ust-Pinega & 23.8 & 74 & 16.7 & 1.22 & 13.73 & 2.1 & 47 & -0.7 & 1.94 & -0.37 \\
\hline Onega & Porog & 20.2 & 61 & 2.4 & 1.21 & 1.99 & 2.4 & 37 & -0.1 & 2.00 & -0.05 \\
\hline Mezen & Malonisogo-rskaya & 29.6 & 77 & 3.6 & 1.22 & 2.97 & 2.3 & 46 & -0.1 & 1.98 & -0.05 \\
\hline Pechora & Ust-Cilma & 41.5 & 73 & 15.1 & 1.26 & 12.02 & 2.0 & 43 & -0.5 & 2.09 & -0.22 \\
\hline Sukhona & Kalikino & 21.6 & 61 & 2.0 & 1.31 & 1.55 & 1.5 & 46 & -0.1 & 1.78 & -0.05 \\
\hline Usa & Adzva & 49.5 & 69 & 5.9 & 1.23 & 4.78 & 1.2 & 35 & -0.1 & 2.40 & -0.03 \\
\hline Vetluga & Vetluga & 22.3 & 58 & 1.2 & 1.28 & 0.92 & 1.0 & 41 & 0.0 & 1.79 & -0.01 \\
\hline Volga & Staritsa & 16.1 & 90 & 0.7 & 1.23 & 0.55 & 1.7 & 66 & 0.0 & 1.65 & -0.02 \\
\hline Moksha & Shevelkovskiy Majdan & 9.2 & 69 & 1.2 & 1.29 & 0.93 & 0.7 & 40 & 0.0 & 2.28 & -0.01 \\
\hline Oka & Gorbatov & 11.6 & 68 & 6.9 & 1.41 & 4.92 & 1.7 & 47 & -0.3 & 2.00 & -0.17 \\
\hline Ugra & Tovarkovo & 12.4 & 73 & 0.6 & 1.23 & 0.45 & 1.6 & 49 & 0.0 & 1.78 & -0.01 \\
\hline Belaya & Birsk & 17.4 & 104 & 5.0 & 1.32 & 3.82 & 1.9 & 67 & -0.2 & 2.12 & -0.11 \\
\hline Vishera & Ryabinino & 42.3 & 68 & 2.5 & 1.26 & 1.97 & 3.6 & 38 & -0.1 & 2.21 & -0.04 \\
\hline Vyatka & Vyatskie Polyani & 19.5 & 87 & 4.7 & 1.24 & 3.81 & 1.6 & 52 & -0.2 & 2.10 & -0.08 \\
\hline Kama & Bondug & 23.3 & 81 & 2.3 & 1.20 & 1.90 & 1.7 & 49 & -0.1 & 2.04 & -0.04 \\
\hline Ufa & Verkhnij Suyan & 18.5 & 87 & 1.1 & 1.33 & 0.82 & 1.6 & 50 & -0.1 & 2.24 & -0.03 \\
\hline Don & Kazanskaya & 6.3 & 68 & 3.1 & 1.43 & 2.15 & 1.0 & 44 & -0.1 & 2.14 & -0.04 \\
\hline Medvedica & Archedinskaya & 4.2 & 68 & 0.8 & 1.43 & 0.57 & 0.4 & 50 & 0.0 & 1.90 & -0.01 \\
\hline Khoper & Besplemya-novskiy & 6.7 & 65 & 1.3 & 1.49 & 0.87 & 0.5 & 51 & 0.0 & 1.88 & -0.01 \\
\hline
\end{tabular}

the more it's runoff as abnormally low or high. In world practice in such estimates is often used so-called index of severity (Sev). It is the ratio of the excess or shortage of water for the duration of this phenomenon.

$\operatorname{Sev}_{i}=\frac{\Delta V_{i}}{T}$,

where Sev is the indicator of severity; $\Delta V$ is the deficit or surplus, $\mathrm{km}^{3} ; T$ is the duration of abnormally low or high values of discharge, days; $i$ is the probability, $\%$.

The data obtained enable to calculate severity of the conditions for excess and deficiency of water (Table 1). At extremely high flow the severity of the studied rivers varies from $0.55-0.57$ in the Don basin and the Upper Volga to 13.7 in the basin of the Northern Dvina. There is a close relationship between the severity and the catchment area (Fig. 6a). With the increase in the catchment area severity rises quite rapidly. At extremely low flow rates the severity varies from 0.1 in the basin of the Upper Volga and the Don to 0.37 in the basin of the Northern Dvina. Dependence is also a linear - the higher the catchment area, the greater the severity of water shortages, observed on the river (Fig. 6b).

For some regions there is a tendency to group the most extreme years in time. So, in the basins of the northern rivers, the most severe water shortage occurred in 1938-1945 and 1965-1975 were extremely abounding. Water scarcity is observed on these rivers also in the 2000s. In the basin of the Upper Volga were extremely dry 1945, 1950, 1967-1969, and abounding - 1966, 1974, 1947-1958. But last case of the extreme shortages was 1977, according to calculations. So, conditions of 2010 and 2014 are completely normal for water regime. Tributaries of the Volga behave somewhat differently. On the Oka, Ugral, Moksha water shortage is mainly observed in the 1937-1939, and the high-water period was in 1958, 1970, 1979-1981. Last deficits observed here in 19731975 (except p. Moksha, which tends to Kama river basin). By the rivers of the Kama basin water shortage observed in the 1920s-1940s, and water excess - in 1960-1970s and early 1990s. However, even in recent years $(2006,2008)$ as well as from 1976 to 1977 some deficiencies are allocated here.

Dynamic of the extreme rates is also very interesting. Northern rivers are characterized by smooth increase in elevation above the thresholds, and the reduction in deficits. The frequency of occurrence of extreme water discharges is reduced from $80-100 \%$ at the start of observations up to 20 $30 \%$ at the moment. For instance, the deficits on the Northern Dvina, mostly observed in the 30s-40s. After that began a steady decline in the frequency of water shortages, but the duration of the deficits, on the contrary increased from 12 months to 3 and sometimes 4 , and its volume decreased. On Onega and Mezen trends are very different from other rivers. Here comes the decline in excess water and increase in deficits. In the basin of the Upper Volga different picture is observed. There is a marked decrease in volume of extremly high water events and simultaneous decline in deficits - the water regime significantly leveled. To the east of the region - in Kama basin, different pattern observed, similar to the trend in the north ETR. There is a smooth increase in water excess and decline in deficits. Low-flow period becomes less deep and volume of seasonal-flood conversely increases. The 


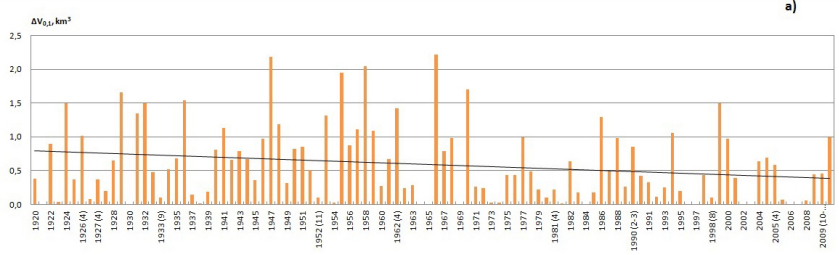

b)

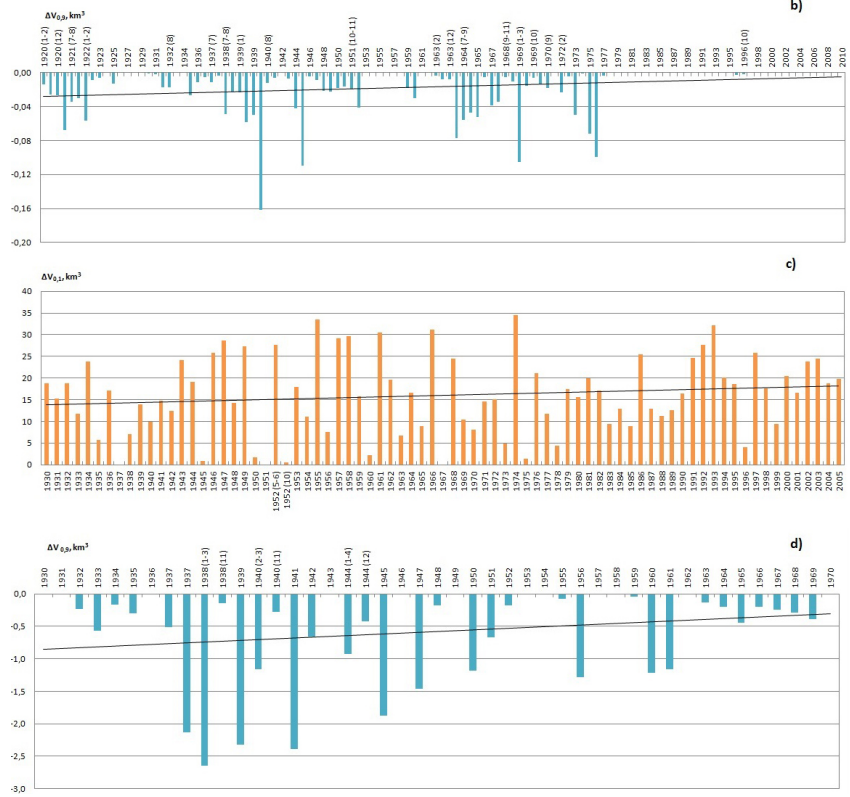

Figure 6. Volume of surplus (a) and deficit (b) for the VolgaStaritsa and volume of surplus (c) and deficit (d) for the N. DvinaUst-Pinega.

southern part of the ETP, Don and Oka shows the most obvious changes. Surplus reduced at times, and deficits in general no longer occur since 1975-1977.

\section{Conclusions}

Summing up, it should be noted that according to the calculations arising now extreme hydrological events are not exclusive. During the period of long-term observations, there are cases of deeper water shortages. All the rivers of the European part of Russia is characterized by a reduction of scarce periods. For the Volga and the Don River basin real deficits in general no longer occur since 1975-1977 mostly. If we talk about the extremely high water periods, for the Northern Rivers and the basin of the Kama frequency and severity of such events increases, while for the south and center of the region, by contrast, is reduced.
Acknowledgements. The study was supported by the Russian Science Foundation (grant no. 14-17-00700).

\section{References}

Alekseevskiy, N. I., Frolova, N. L., Grechushnikova, M. G., and Pakhomova, O. M.: Negative impact assessment of low flow period 2010 on the socio-economic complex of Russia, Theoreticalpractical journal, 3, 65-68, 2013 (in Russian).

Dzhamalov, R. G., Frolova, N. L., and Kireeva, M. B.: Current changes in river water regime in the Don River Basin, Water Resour., 40, 573-584, $2013 \mathrm{a}$.

Dzhamalov, R. G., Frolova, N. L., Kireeva, M. B., Telegina, A. A., and Telegina, E. A.: Present-day surface and subsurface water supply in the Oka river basin, Subsurface management - XXI century, 6, 40-45, 2013b (in Russian).

Dzhamalov, R. G., Frolova, N. L., Kireeva, M. B., and Rets, E. P.: Present-day surface and subsurface water resources of European Russia: conditions, use and forecast, IAHS Publ. 363, 215-220, 2014.

Frolova, N. L., Kireeva, M. B., Nesterenko, D. P., Agafonova, S. A., and Tersky, P. N.: Up-to-date climate forced seasonal flood changes (the case study for European part of Russia), IAHS Publ. 363, 113-118, 2014.

Kireeva, M. B. and Frolova, N. L.: Modern features of spring flood for the Don river basin, Water Management Russia: problems, technology and management, 1, 60-76, 2013 (in Russian). 